This is an electronic reprint of the original article. This reprint may differ from the original in pagination and typographic detail.

Author(s): Kiuru, Noona; Laursen, Brett; Aunola, Kaisa; Zhang, Xiao; Lerkkanen, Marja-Kristiina; Leskinen, Esko; Tolvanen, Asko; Nurmi, Jari-Erik

Title: $\quad$ Positive Teacher Affect and Maternal Support Facilitate Adjustment After the Transition to First Grade

Year: $\quad 2016$

Version:

Please cite the original version:

Kiuru, N., Laursen, B., Aunola, K., Zhang, X., Lerkkanen, M.-K., Leskinen, E., Tolvanen, A., \& Nurmi, J.-E. (2016). Positive Teacher Affect and Maternal Support Facilitate Adjustment After the Transition to First Grade. Merrill-Palmer Quarterly, 62(2), 158178. https://doi.org/10.13110/merrpalmquar1982.62.2.0158

All material supplied via JYX is protected by copyright and other intellectual property rights, and duplication or sale of all or part of any of the repository collections is not permitted, except that material may be duplicated by you for your research use or educational purposes in electronic or print form. You must obtain permission for any other use. Electronic or print copies may not be offered, whether for sale or otherwise to anyone who is not an authorised user. 


\title{
Positive Teacher Affect and Maternal Support Facilitate Adjustment After the Transition to First Grade
}

\author{
Noona Kiuru University of Jyväskylä \\ Brett Laursen Florida Atlantic University \\ Kaisa Aunola University of Jyväskylä \\ Xiao Zhang Hong Kong Institute of Education \\ Marja-Kristiina Lerkkanen, Esko Leskinen, \\ Asko Tolvanen, and Jari-Erik Nurmi University of Jyväskylä
}

This longitudinal study, conducted among a sample of Finnish primary-school children, examined the proposition that a single high-quality relationship (either with a teacher or a parent) can buffer against adjustment problems. Teachers rated the externalizing problems and prosocial behaviors of 378 children in Grade 1 and again in Grade 2. Relationship measures gathered in Grade 1 included teacher reports of positive affect for the child and mother reports of support for the child. The results supported our proposition by showing that for child adjustment after the transition to primary school it was critical to have at least one high-quality relationship either with a teacher or a parent. High positive teacher affect in Grade 1 buffered against adjustment problems for children with low maternal support, whereas high maternal support in Grade 1 buffered against adjustment problems for children with low positive teacher affect. In turn, children who received low support from both teachers and parents showed the poorest adjustment.

Noona Kiuru, Kaisa Aunola, Asko Tolvanen, Jari-Erik Nurmi, and Brett Laursen, Department of Psychology; Xiao Zhang, Department of Early Childhood Education; Marja-Kristiina Lerkkanen, Department of Teacher Education; and Esko Leskinen, Department of Mathematics and Statistics.

This study was funded by a grant from the Academy of Finland to the Finnish Center of Excellence in Learning and Motivation Research (No. 213486) and other grants from the same funding agency to Noona Kiuru (No. 7133146), Kaisa Aunola (No. 7119742), and MarjaKristiina Lerkkanen (No. 125811). Brett Laursen received support from the U.S. National Science Foundation (No. 0923745, No. 0909733).

Address correspondence to Noona Kiuru, Department of Psychology, University of Jyväskylä, PO Box 35, F-40014 Jyväskylä, Finland. Phone: +358 40805 4740. E-mail: noona.h.kiuru @ jyu.fi.

Merrill-Palmer Quarterly, April 2016, Vol. 62, No. 2, pp. 158-178. Copyright () 2016 by Wayne State University Press, Detroit, MI 48201. 
The transition to primary school can be both challenging and stressful for a child (Ladd, 1990; Niesel \& Griebel, 2007). How children negotiate the move to formal schooling has an important and long-lasting effect on their school careers (Entwisle \& Alexander, 1998). At school entry, a child is expected to follow the teacher's directions, show persistence in completing activities, and attend to instruction (Campbell \& Stauffenberg, 2007). In addition, a child is expected to cooperate and form relationships with a new teacher and classmates. Although most children cope well with these new demands, successful adaptation is not assured. Positive relationships with teachers, characterized by high levels of warmth and support, can facilitate a successful transition to school (Pianta \& Hamre, 2009; RimmKaufman \& Pianta, 2000). Children who receive emotional support from their teacher feel more connected to school, present fewer problem behaviors, and display greater self-directness and social competence than children who feel unsupported by teachers (Birch \& Ladd, 1997; Mashburn et al., 2008). In turn, lack of emotional support and lack of positive teacher affect may lead to problems in school adjustment. Some evidence suggests that, in particular, low-achieving children (Burchinal, PeisnerFeinberg, Pianta, \& Howes, 2002) and children with externalizing problems (Ladd \& Burgess, 2001; Meehan, Hughes, \& Cavell, 2003; Silver, Measelle, Armstrong, \& Essex, 2005) benefit from a positive relationship with a teacher. Less is known, however, about whether teachers can compensate for interpersonal relationship difficulties, particularly problems with parents, and whether parental support can compensate for difficulties encountered in the teacher-child relationship. The present study tested the proposition that a single high-quality relationship (either with a teacher or a parent) can buffer against adjustment problems (Laursen \& Mooney, 2008) in a sample of Finnish children who were investigated in Grades 1 and 2 of primary school. We expected positive teacher affect to buffer against adjustment problems associated with low maternal support, and high maternal support to buffer against adjustment problems associated with lack of positive affect.

\section{Role of the Teacher-Child Relationship in Children's Adjustment Behaviors}

The teacher-child relationship describes the quality of the interaction between a teacher and a child (Davis, 2003; Pianta, 1999). As such, it is distinct from teaching practices, which refer to the concrete actions through which teachers aim to attain their teaching goals. It has been suggested that the teacher-child relationship embodies two relatively independent 
dimensions: (a) a positive dimension reflecting closeness, warmth, and positive affect, and (b) a negative dimension reflecting disconcordance, anger, and difficulties in the modulation of negative experiences (Spilt \& Koomen, 2009). In the present study, we focus on the positive dimension of the teacher-child relationship. Teachers' positive affects toward the child in teaching situations was used as an indicator of a warm and close teacher-child relationship. Teacher report of positive emotions toward a particular student has been found to be closely related to sensitive teaching practices and closeness of the teacher-student relationship (Spilt \& Koomen, 2009).

There are several theoretical justifications for why a positive teacherchild relationship is important during the transition to primary school. The attachment-theory perspective (Howes, 1999; Pianta, Nimetz, \& Bennett, 1997) suggests that, as they negotiate the demands of school, a close and positive relationship with the teacher provides children with security and emotional support (Doumen, Koomen, Buyse, Wouters, \& Verschueren, 2012; Hamre \& Pianta, 2001; Spilt, Koomen, Thijs, \& van der Leij, 2012). For example, a positive relationship with a teacher provides a safe context for the development of self-regulation (Denham \& Burton, 1996). Warm, supportive teachers also use sensitive ways to guide children who are misbehaving and direct them toward constructive social problem solving (Thijs, Koomen, \& van der Leij, 2008). In addition, a close, supportive relationship with a teacher may fulfill the child's basic psychological need for social relatedness (Baumeister \& Leary, 1995; Deci \& Ryan, 2000). When this need is met, children feel connected to the classroom, which in turn fosters motivation to behave in socially appropriate ways (see also Davis, 2003; Roorda, Koomen, Spilt, \& Oort, 2011) and concentrate on learning (Kiuru et al., 2014; Wang \& Eccles, 2012).

Empirical evidence has been adduced in support of the view that a positive relationship with a teacher facilitates a child's adaptation at the beginning of formal schooling and onward. Helping a student to feel valued and accepted, and engaging in emotionally warm and positive interactions, have been shown to optimally scaffold students' academic achievement and adjustment (La Paro, Pianta, \& Stuhlman, 2004; Pianta, 1999). For example, close, supportive teacher-child relationships predict improved prosocial skills (Berry \& O'Connor, 2010) and lower levels of behavior problems across the primary-school years (Blacher, Baker, \& Eisenhower, 2009). Furthermore, a positive teacher-child relationship at the beginning of formal schooling has been shown to have a long-term positive impact on academic achievement and adaptation through the middle-school years 
and beyond (Hamre \& Pianta, 2001). These findings also hold when relationship quality is assessed by teachers (O'Connor \& McCartney, 2007; Pianta, Steinberg, \& Rollins, 1995), students (Skinner \& Belmont, 1993), or observers (Ladd, Birch, \& Buhs, 1999).

\section{Associations Between Positive Teacher Affect and Adjustment Among Children with Low Support From Parents}

Teacher influence is unlikely to be same for all children. A close, supportive relationship with a teacher, who is an important role model in the early primary grades, may be particularly important for children who lack other forms of support during the transition to primary school. The deficit model of interpersonal relationships (Laursen \& Mooney, 2008) posits that a single high-quality relationship might compensate or buffer against adjustment difficulties associated with suboptimal levels of support in other relationships. Accordingly, the impact of the teacher-child relationship on a child's school adjustment may be best understood in the context of other social relationships.

One important social relationship for a child is that with the parents. Low support from parents is a stressor that can interfere with subsequent school adjustment (Gauze, Bukowski, Aquan-Assee, \& Sippola, 1996). Parental support or affection (e.g., responsiveness, involvement, and supportiveness) refers to parents' connectedness to the child and the interactional warmth between parent(s) and child (Aunola \& Nurmi, 20015; Galambos, Barker, \& Almeida, 2003; Wood, McLeod, Sigman, Hwang, \& Chu, 2003). Whereas parental support has been suggested to facilitate children's adjustment (Gray \& Steinberg, 1999; Siequeland, Kendall, \& Steinberg, 1996), parenting characterized by low warmth and support has been shown to undermine the development of children's self-regulation and social skills (e.g., Cunningham, Kliewer, \& Garner, 2009; Eisenberg et al., 2001; Hart, Newell, \& Olsen, 2003). Overall, a supportive and affective relationship with both teachers and parents seems to be important for school adjustment.

It has also been suggested that these two relationships may interact (see also Crosnoe \& Elder, 2004). On the one hand, a close relationship with a teacher at school entry may overcome some of the risks for successful adaptation to primary school posed by low parental support. For example, teacher closeness has been found to buffer insecurely attached young children against heightened levels of aggressive behavior (Buyse, Verschueren, \& Doumen, 2009) and against poor academic achievement 
(O'Connor \& McCartney, 2007). Teacher support also facilitates improved prosocial behavior among preschoolers with depressed mothers (Johnson, Seidenfeld, Izard, \& Kobak, 2013). In adolescent samples, evidence has also been found that a positive teacher-student relationship can help adolescents with a conflictual parent-adolescent relationship to attain less behaviorally delinquent developmental trajectories across time (Wang, Brinkworth, \& Eccles, 2013). In another study among adolescents, Crosnoe and Elder (2004) found that close relationships with teachers protected against parent-related academic risk for offtrack academic behavior among Asian American adolescents. However, not all studies with child (Pianta et al., 1997) or adolescent (Wentzel, 1998) samples have demonstrated interactive effects between the parent-child and the teacher-child relationship.

On the other hand, parental support might buffer against difficulties encountered in the teacher-child relationship. Furthermore, in line with the deficit model of interpersonal relationships (Laursen \& Mooney, 2008), a single high-quality relationship (whether with a parent or a teacher) might be a sufficient buffer against adjustment problems. Although some work has been done on the interaction between a warm and close relationship with a teacher and parental support, none of these studies have focused on the first grades of primary school, which have critical importance for subsequent academic, career, and mental health outcomes (Entwisle \& Alexander, 1998). Moreover, although supportive parenting might also buffer against a poor teacher-child relationship, only a few studies thus far have examined this possibility.

\section{Research Questions and Hypotheses}

This study investigated the longitudinal associations between the quality of teacher-child and mother-child relationships and the child's externalizing problems and prosocial behavior among Finnish students from first grade to second grade. Moreover, we examined the interactive effects of positive teacher affect for the child and maternal support on child adjustment behaviors after the critical transition to primary school. Consistent with the deficit model (Laursen \& Mooney, 2008), we predicted that positive relations with teachers would buffer against adjustment problems associated with low maternal support and that maternal support would buffer against adjustment problems associated with lack of positive teacher affect. The poorest adjustment outcomes were expected for students who received low support from both teachers and parents (Sameroff, 1993). 


\section{Method}

\section{Participants and Procedures}

The participants were drawn from the First Steps longitudinal study that followed approximately 2,000 children during the transition to primary school. The sample was drawn from four municipalities in different regions of Finland. In three municipalities, the entire age cohort participated and, in the fourth municipality, about half of the age cohort participated. A total of 2,383 students were invited to participate. Of this total, $79 \%(n=1,880)$ participated. Parental written consent and child assent were required for student participation. Also, teachers were asked for their written consent to participate.

To enable a more thorough evaluation of child development, a target sample of 378 children (183 girls and 195 boys) was drawn from a larger sample of 1,880 children by making random student selections from each classroom. Target sampling was necessary so as to decrease the datacollection demands placed on teachers. The number of target children selected from a classroom was typically 2 or $3(M=2.53, S D=0.84)$ but ranged from 1 (in the smallest classes) to 4 (in the largest classes). The target students came from 94 schools (151 classrooms). In Finnish schools, children typically have the same teacher for all academic subjects in both Grades 1 and 2. In this study, the teachers of about two-thirds of target children remained unchanged from Grade 1 to Grade 2.

At the beginning of this study (Grade 1), the children were about 7 years old. At study commencement, most of the children (77\%) lived in two-biological-parent families; the remainder lived in single-parent families $(12 \%)$ or blended families $(11 \%)$. In 5\% of families, the parents had not been educated beyond comprehensive school (compulsory education up to Grade 9), 26\% had completed upper secondary education (senior high school or vocational school, Grades 10-12), 38\% had a bachelor's degree or vocational college degree (3-year education at a college or university), and $31 \%$ had a master's degree or higher (i.e., licentiate or doctorate). The sample was fairly representative of the Finnish population (Statistics Finland, 2007), in which during the same period 6\% of families had only basic education ( 9 years of formal education), $30 \%$ upper secondary education (high school or vocational school), 35\% a vocational college degree or bachelor's degree, and $29 \%$ a master's (5-year university education) or higher university degree.

The data for the present study were collected in Grades 1 and 2 . Teachers rated the externalizing problems and prosocial behaviors of the target children in Grade 1 fall and Grade 2 spring. Teacher reports of 
positive affect for each target child were collected in the spring of Grade 1. Maternal reports of support for each target child were also collected in the spring of Grade 1.

\section{Measures}

Externalizing problems and prosocial behaviors in Grades 1 and 2. The first-grade and second-grade teachers completed the Strengths and Difficulties Questionnaire (SDQ; Goodman, 1997), rating the target children on a 3-point scale (from $1=$ does not apply to 3 = certainly applies). The SDQ is a widely used behavioral screening questionnaire that correlates highly with other measures of behavior problems - for example, Child Behavior Checklist (Goodman \& Scott, 1999; Koskelainen, Sourander, \& Kaljonen, 2000). Externalizing problems was measured with 10 items, five measuring conduct problemsfor example, "Generally obedient" (reversed) and "Often fights with other children or bullies them"-and five measuring hyperactivity/ inattention-for example, "Restless, overactive, cannot stay still for long" and "Thinks things out before acting (reversed; Grade 1: Cronbach's $\alpha=.89$; and Grade 2: Cronbach's $\alpha=.90$ ). Prosocial behavior was measured with five items ("Considerate of other people's feelings," "Shares readily with other children," "Helpful," "Kind to younger children," and "Often volunteers to help others"; Grade 1: Cronbach's $\alpha=.82$; and Grade 2: Cronbach's $\alpha=.85$ ). The item scores for externalizing problems (Grade 1: $M=1.43, S D=0.44$; and Grade 2: $M=1.46$, $S D=0.47$ ) and prosocial behavior (Grade 1: $M=2.24, S D=0.50$; and Grade 2: $M=2.21, S D=0.53$ ) were averaged.

Positive teacher affect in Grade 1. The teachers rated their positive affect for each target student in Grade 1 on a 5-point scale (from $1=$ not at all to $5=$ very often) (see also Kiuru et al., 2013, 2014). Positive teacher affect was measured with two items ("When you teach this child how often do you feel satisfied" and "When you teach this child how often do you feel joy"; Cronbach's $\alpha=.90)$. The item scores were averaged $(M=4.17$, $S D=0.80$ ). To check the validity of the variable, Grade 4 teachers also completed the Student-Teacher Relationship Scale (STRS; Pianta, 2001). Grade 4 teacher positive affect correlated $.53(p<.001)$ with the Grade 4 teacher report on the closeness subscale of the STRS. Teacher and observer ratings of teacher-child relationship have been shown to converge to a moderate degree (Doumen et al., 2012).

Maternal support in Grade 1. Mothers completed a revised Finnish version (Aunola \& Nurmi, 2004, 2005) of the Child-Rearing Practices 
Report (CRPR; Roberts, Block, \& Block, 1984) in Grade 1, rating the child on 5-point scale (from $1=$ does not fit me at all to $5=$ fits me very well; for more reliability and validity information on the Finnish sample, see Aunola \& Nurmi, 2004, 2005). Maternal support was measured with a 10-item subscale (e.g., "I often tell my child that I appreciate what he/ she tries out or achieves" and "I often show my child that I love him/ her"; Cronbach's $\alpha=.84)$. The item scores were averaged $(M=4.27$, $S D=0.45)$.

\section{Analytic Strategy}

The present study was designed to investigate the extent to which positive teacher affect for children in Grade 1 and maternal support predicted changes in child adjustment at the beginning of primary school. In addition, we investigated the interactive effects of positive teacher affect for children and maternal support. Figure 1 shows the schematic path

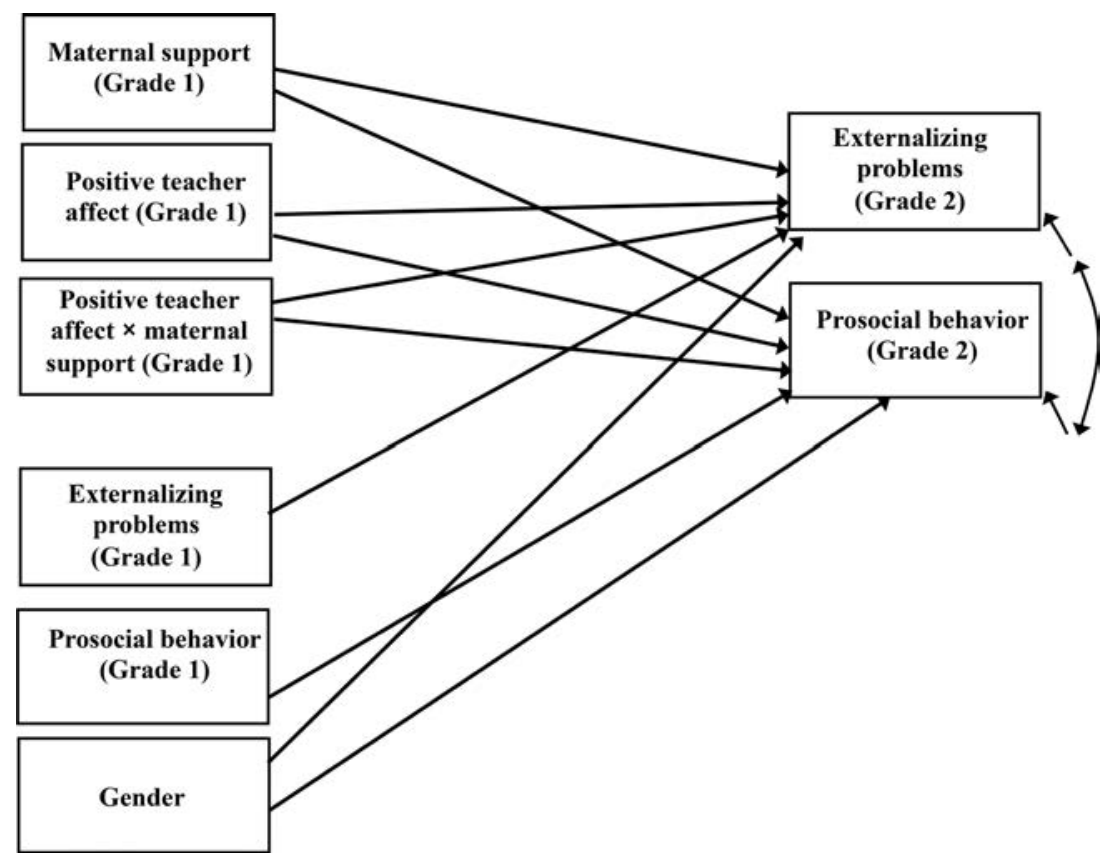

Figure 1. Theoretical path model for relationship measures and children's adjustment behaviors. Note. Predictor variables are allowed to correlate. 
model. In this model, adjustment behaviors (i.e., prosocial skills and externalizing problems) in Grade 2 were predicted by the same adjustment behaviors in Grade 1 and by positive teacher affect toward children and maternal support in Grade 1, as well as by the interaction term of positive teacher affect $\times$ maternal support. Predictors were allowed to correlate. Child's gender was included in the model as a control variable.

The analyses were conducted using Mplus Version 7.0 with the Type $=$ Complex approach (L. K. Muthén \& Muthén, 1998-2013; see also Asparouhov \& Muthén, 2006; B. O. Muthén \& Satorra, 1995). This method estimates the models at the level of the whole sample, correcting the estimation's standard-error and $\chi^{2}$-value distortions caused by clustering of observations (classroom differences). Full-information maximumlikelihood procedures were used to handle missing data. Across the variables, missingness ranged $0 \%-26 \%(M=14 \%, S D=8 \%)$. The largest amount of missing data (i.e., 26\%) was observed for the maternal support variable, which is in line with the response rate $(74 \%)$ in parental questionnaires. The missing completely at random (MCAR) test (R. J. A. Little, 1988) indicated that data in the adjustment and interpersonal variables were missing completely at random and did not depend on demographic characteristics (e.g., child's age, gender, or level of parental education): $\chi^{2}(131)=111.52, p>.05$. The variables were skewed, and hence the Maximum Likelihood Robust (MLR) estimator was used. The MLR produces robust standard errors by means of a sandwich estimator and a chisquare-test statistic for nonnormal outcomes.

\section{Results}

\section{Descriptive Information}

Table 1 presents the correlations among the study variables. Positive teacher affect was positively correlated with maternal support and prosocial behavior, and was negatively correlated with externalizing problems. Maternal support was negatively correlated with externalizing problems and positively correlated with prosocial behavior. Independent samples $t$ tests explored mean-level gender differences. (See also Table 1 for correlations of gender with the other study variables.) Relative to girls, boys showed more externalizing problems (Grade 1: Cohen $d=0.74$; and Grade 2: Cohen $d=0.80$ ) and less prosocial behavior (Grade 1: Cohen $d=0.74$; and Grade 2: Cohen $d=0.73$ ). Teachers reported more positive affect in Grade 1 for girls than for boys (Cohen $d=0.41$ ). 
Table 1. Correlations between study variables

\begin{tabular}{|c|c|c|c|c|c|c|c|}
\hline Variable & 1 & 2 & 3 & 4 & 5 & 6 & 7 \\
\hline $\begin{array}{l}\text { 1. Externalizing } \\
\text { problems (Grade 1) }\end{array}$ & 1.00 & & & & & & \\
\hline $\begin{array}{l}\text { 2. Externalizing } \\
\text { problems (Grade 2) }\end{array}$ & $.77^{* \star \star}$ & 1.00 & & & & & \\
\hline $\begin{array}{l}\text { 3. Prosocial behavior } \\
\text { (Grade 1) }\end{array}$ & $-.54^{* * *}$ & $-.43^{* * *}$ & 1.00 & & & & \\
\hline $\begin{array}{l}\text { 4. Prosocial behavior } \\
\text { (Grade 2) }\end{array}$ & $-.44^{* * *}$ & $-.58^{* * *}$ & $.63^{* * *}$ & 1.00 & & & \\
\hline $\begin{array}{l}\text { 5. Positive teacher } \\
\text { affect (Grade 1) }\end{array}$ & $-.41^{* * *}$ & $-.40^{\star \star *}$ & $.32^{* * *}$ & $.33^{* * *}$ & 1.00 & & \\
\hline $\begin{array}{l}\text { 6. Maternal support } \\
\text { (Grade 1) }\end{array}$ & $-.20^{*}$ & $-.24^{* * *}$ & $.13^{*}$ & $.16^{* *}$ & $.28^{* * *}$ & 1.00 & \\
\hline 7. Gender ${ }^{a}$ & $.36^{* * *}$ & $.38^{* * *}$ & $-.35^{\star \star *}$ & $-.36^{* \star *}$ & $-.21^{* \star *}$ & .02 & 1.00 \\
\hline
\end{tabular}

Note. $N=374$.

${ }^{\mathrm{a}}$ Girl $=0$; boy $=1$.

${ }^{*} p<.05$.

${ }^{* *} p<.01$.

${ }^{* * *} p<.001$.

\section{Maternal Support and Positive Teacher Affect as Predictors of Change in Child Adjustment Behaviors}

Table 2 lists the standardized path coefficients of the path analysis in which children's externalizing problems and prosocial behavior in Grade 2 were predicted by maternal support and positive teacher affect for the child in Grade 1, after controlling for externalizing problems and prosocial behavior in Grade 1. The model fit the data well: $\chi^{2}(2)=0.90, p=.64$, root mean square error of approximation $=0.00$, comparative fit index $=1.00$, and standardized root mean square residual $=0.01$. The results showed, first, that both externalizing problems and prosocial behavior showed considerable stability from Grade 1 to Grade 2. In addition, boys showed more externalizing problems and less prosocial behavior in Grade 2 after Grade 1 behaviors had been controlled for. Positive teacher affect and maternal support had no significant main effects on subsequent adjustment behaviors, except that maternal support was marginally significantly associated with a lower subsequent level of externalizing problems. However, the interaction effect, Positive Teacher Affect $\times$ Maternal Support, was significant when predicting both externalizing problems and prosocial behaviors. 
Table 2. Standardized path coefficients for relationship measures and children's adjustment behaviors

\begin{tabular}{lcc}
\hline & $\begin{array}{c}\text { Externalizing problems } \\
\text { (Grade 2) }\end{array}$ & $\begin{array}{c}\text { Prosocial behavior } \\
\text { (Grade 2) }\end{array}$ \\
\hline $\begin{array}{l}\text { Control variables } \\
\text { Externalizing problems /pro- } \\
\text { social behavior (Grade 1) } \\
\text { Gender }\end{array}$ & $.66^{* * *}$ & $.52^{* * *}$ \\
$\begin{array}{l}\text { Variables of main interest } \\
\text { Maternal support (Grade 1) }\end{array}$ & $.13^{* *}$ & $-.15^{* *}$ \\
$\quad \begin{array}{l}\text { Positive teacher affect } \\
\text { (Grade 1) } \\
\text { Positive teacher affect x }\end{array}$ & $-.08^{+}$ & .05 \\
maternal support (Grade 1) & -.06 & .10 \\
& $.10^{*}$ & $-.14^{* *}$ \\
\hline
\end{tabular}

Note. ${ }^{\text {a }}$ Girl $=0$; boy $=1$.

${ }^{*} p<.05$.

${ }^{* *} p<.01$.

${ }^{* * *} p<.001$.

${ }^{+} p<.10$, two-tailed.

To investigate this interaction effect in more detail, we calculated (a) the simple slopes for maternal support as a predictor of child adjustment behaviors separately for children with a low level of positive teacher affect $(-1 S D)$ and for children with a high level of positive teacher affect $(+1$ $S D$ ) (see Figure 2) and (b) the simple slopes for positive teacher affect as a predictor of child adjustment behaviors separately for children with a low maternal support $(-1 S D)$ and for children with high maternal support (+1 SD) (Figure 3). We also used the computational tool developed by Preacher, Curran, and Bauer (2006) to calculate the statistical significance of these simple slopes.

Positive teacher affect as a moderator (Figure 2). For children with a low level of positive teacher affect, high maternal support predicted decreasing externalizing problems $(\beta=-.18, S E=0.06, p=.0047)$ and increasing prosocial behavior $(\beta=.19, S E=0.05, p<.001)$. For children with a high level of positive teacher affect, externalizing problems $(\beta=$ $0.02, S E=0.06, p=.75)$ and prosocial behavior $(\beta=-.09, S E=0.08$ $p=.26$ ) did not change as a function of maternal support. When maternal support and positive teacher affect were both low, the child exhibited high 

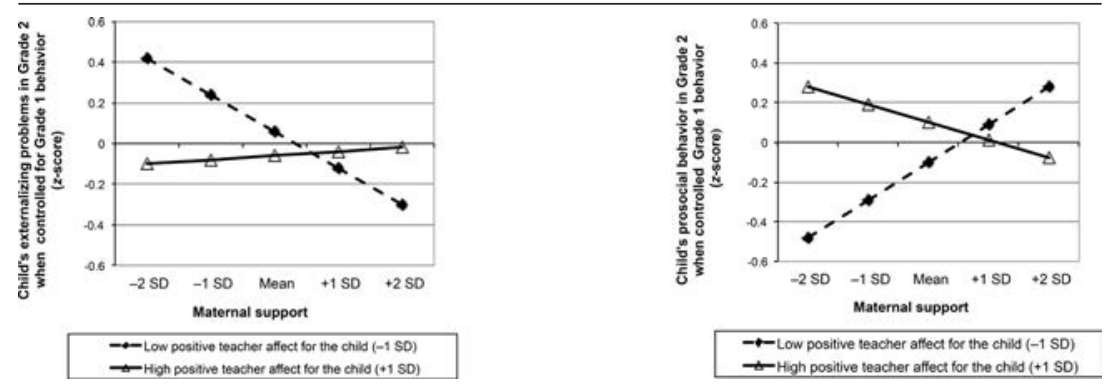

Figure 2. Positive teacher affect as a moderator of the associations between maternal support and subsequent adjustment behaviors: (left) between maternal support and externalizing problems and (right) between maternal support and subsequent prosocial behavior.
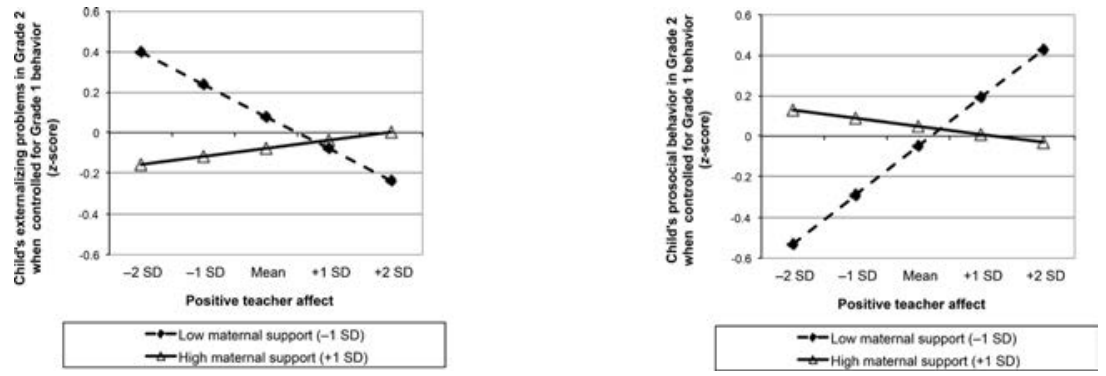

Figure 3. Maternal support as a moderator of the associations between positive teacher affect and subsequent adjustment behaviors: (left) between positive teacher affect and externalizing problems and (right) between positive teacher affect and subsequent prosocial behavior.

levels of externalizing problems and low levels of prosocial behavior. By contrast, when positive teacher affect was high, the child exhibited low levels of externalizing problems and high levels of prosocial behavior independently of the level of maternal support. In other words, positive teacher affect toward the child buffered against adjustment difficulties for children receiving low support from their mothers.

Maternal support as a moderator (Figure 3). For children with a low level of maternal support, high positive teacher affect predicted decreasing externalizing problems $(\beta=-.16, S E=0.06, p=.014)$ and increasing prosocial behavior $(\beta=.24, S E=0.08, p=.038)$. For children with a high level of maternal support, externalizing problems $(\beta=0.04, S E=0.06, p=.54)$ and prosocial behavior $(\beta=-.04, S E=0.08, p=.63)$ did not change as a 
function of positive teacher affect. When positive teacher affect and maternal support were both low, the child exhibited high levels of externalizing problems and low levels of prosocial behavior. By contrast, when maternal support was high, the child exhibited low levels of externalizing problems and high levels of prosocial behavior independently of the level of positive teacher affect. In other words, high maternal support buffered against adjustment difficulties for children receiving low positive teacher affect.

\section{Supplementary Analyses}

Two sets of supplementary analyses were conducted. First, given the potential for the associations among the variables of interest to differ with change of informant (i.e., teacher), the multigroup method was used to compare the results between the students who had the same teacher $(70 \%, n=266)$ and those whose teacher changed (30\%, $n=112)$ from Grade 1 to Grade 2. The Satorra-Bentler scaled chi-square difference tests showed that the fit of the model was not significantly decreased when the paths were constrained to be equal $(p>.05)$. Therefore, the associations between maternal support, positive teacher affect for the child, and children's adjustment behaviors did not differ among students who remained with the same teacher and those whose teacher changed from Grade 1 to Grade 2.

Finally, to ensure that gender did not moderate the associations, multigroup models compared girls $(n=183)$ and boys $(n=195)$ on patterns of associations. The Satorra-Bentler scaled chi-square tests for difference revealed no statistically significant decline in model fit when the paths for girls and boys were constrained to be equal $(p>.05)$.

\section{Discussion}

This study tested the proposition that a single high-quality relationship (either with a teacher or a parent) can buffer against elementary-school students' adjustment problems. The results showed that high positive teacher affect buffered against the development of adjustment problems from Grade 1 to Grade 2 for children with low maternal support. The results also revealed, conversely, that high maternal support buffered against the development of adjustment problems from Grade 1 to Grade 2 for children with lack of positive teacher affect. These results support the deficit model of relationships (Laursen \& Mooney, 2008), suggesting that a single highquality relationship can buffer against adjustment problems associated with another, low-quality, relationship. Previous studies have shown that 
teachers may compensate for preschool children's relationship problems with parents and peers (Buyse, Verschueren, \& Doumen, 2009; Johnson et al., 2013; M. Little \& Kobak, 2003). The results of the present study suggest that maternal support may also compensate for relationship problems with the teacher. The present study is among the first longitudinal studies to demonstrate buffering effects after the critical transition to primary school.

There are several potential mechanisms that may explain the result that high positive teacher affect buffered against the development of adjustment problems for children with low maternal support. For example, warm teachers can serve as attachment figures, providing "repairing" experiences for children who receive little affection at home (see also Buyse et al., 2009). Moreover, supportive teachers may fulfill basic psychological needs in children (Deci \& Ryan, 2000; Wentzel, 2002). Children whose social relatedness needs are not fulfilled elsewhere may be particularly sensitive to signs of acceptance and validation from teachers. This may make these children more responsive to informal social skills instruction. In addition, children with less supportive parents typically have more social skill deficits than children with more supportive parents (Rothbaum, Rosen, Pott, \& Beatty, 1995), which makes them especially good candidates for compensatory efforts by teachers. Overall, the results suggest that positive teacher affect is particularly important for the adjustment of children who receive low maternal support, whereas high maternal support is particularly important for those who lack positive teacher affect.

The results of the present study also showed that maternal support remains important during the transition to primary school (Gray \& Steinberg, 1999; Pianta et al., 1997). If a child had a close, supportive relationship with his or her mother, lack of emotional support and positive affect from the teacher at the beginning of formal schooling did not lead to problems in subsequent school adjustment. One possible explanation for this result is that maternal support can compensate for insufficient support experienced by a child from another significant other, in this instance the teacher, and so provide a secure foundation for the child in negotiating this important transition. It is also possible that maternal support strengthens children's positive sense of themselves (Ojanen \& Perry, 2007), which then decreases the detrimental impact of lack of positive teacher affect on child adjustment.

Of equal importance is the finding that the poorest adjustment was found among children who received low support from both teachers and parents. The greatest increases in externalizing problems and the greatest decreases in prosocial behavior were found among those whose teachers and mothers both reported the lowest levels of positive 
affect or support for the child. These findings support the cumulative model of risk (Sameroff, 1993), suggesting that accumulating adversity (in this case, social relationship problems) anticipates the accumulation of adjustment difficulties after the challenging transition to primary school. Going forward, we would expect adjustment troubles to snowball because problems cascade across domains (Bukowski, Laursen, \& Hoza, 2010). From a practical perspective, our results suggest that both teachers and parents should make an effort to develop emotionally supportive interactions with children. Building a secure classroom environment during the first years of school may well provide years of dividends in terms of children's adjustment and engagement in learning. Similarly, parental social support remains important during the transition to primary school, suggesting that parents should continue giving their children positive support in their schoolwork.

\section{Limitations and Future Directions}

This study is not without its limitations. First, we used teacher reports of positive teacher affect toward the child in teaching situations as an indicator of a warm, close teacher-child relationship. In future research, it would be important to collect information from both teacher and child and to complement this information with classroom observations. Also, despite being highly reliable, our positive teacher-affect measure consisted of only two items. Furthermore, our approach is narrower than that of the STRS measure (Pianta, 2001), which encourages teachers to consider not only their own thoughts, feelings, or behaviors when self-rating but also the child's reactions to their behaviors and teaching. Finally, we focused solely on the positive teacher-child relationship and therefore did not investigate other aspects of the teacher-child relationship, such as conflict and dependency, that could adversely impact children. A further important question for future research concerns the possible predictive associations between the different relationship domains over time (see also Hughes \& Chen, 2011; Leflot, van Lier, Verschueren, Onghena, \& Colpin, 2011).

\section{Conclusion}

This study provides new insights into the interactive role of teachers' positive affect and maternal support at formal school entry. The results showed that a single high-quality relationship (irrespective of whether it is with a teacher or a parent) can buffer against adjustment problems. High positive teacher affect can compensate for the negative effect of low maternal 
support, whereas high maternal support can compensate for the negative effect of a lack of positive teacher affect. In turn, adjustment problems were most evident among those who received low support or low positive affect from both their teacher and mother. Although teachers have to work hard to build a positive relationship with children who have difficulties in interpersonal relationships, such effort is worthwhile because it can significantly promote the future adjustment of these at-risk children. In a review, Jennings and Greenberg (2009) concluded that many models of training and support show great promise for improving teachers' social and emotional competence and, in turn, helping them to develop and maintain supportive teacher-child relationships. Similarly, all possible efforts should be made to provide supportive parent-child relationships for all children during the critical transition to primary school.

\section{References}

Asparouhov, T., \& Muthén, B. (2006). Multilevel modeling of complex survey data. In Proceedings of the Joint Statistical Meeting, Survey Research Methods Section (pp. 2718-2726). Washington, DC: American Statistical Association.

Aunola, K., \& Nurmi, J.-E. (2004). Maternal affection moderates the impact of psychological control on a child's mathematical performance. Developmental Psychology, 40, 965-978.

Aunola, K., \& Nurmi, J.-E. (2005). The role of parenting styles in children's problem behavior. Child Development, 76, 1144-1159.

Baumeister, R. F., \& Leary, M. R. (1995). The need to belong: Desire for interpersonal attachments as a fundamental human motivation. Psychological Bulletin, 117, 497-529.

Berry, D., \& O'Connor, E. (2010). Behavioral risk, teacher-child relationships, and social skill development across middle childhood: A child-by-environment analysis of change. Journal of Applied Developmental Psychology, 31, 1-14.

Birch, S. H., \& Ladd, G. W. (1997). The teacher-child relationship and children's early school adjustment. Journal of School Psychology, 35, 67-79.

Blacher, J., Baker, B. L., \& Eisenhower, A. S. (2009). Student-teacher relationship stability across early school years for children with intellectual disability or typical development. American Journal of Intellectual Disabilities, 114, 332-339.

Bukowski, W. M., Laursen, B., \& Hoza, B. (2010). The snowball effect: Friendship moderates escalations in depressed affect among avoidant and excluded children. Development and Psychopathology, 22, 749-757.

Burchinal, M. R., Peisner-Feinberg, E., Pianta, R. C., \& Howes, C. (2002). Development of academic skills from preschool through second grade: Family 
and classroom predictors of developmental trajectories. Journal of School Psychology, 40, 415-436.

Buyse, E., Verschueren, K., \& Doumen, S. (2009). Preschoolers' attachment to mother and risk for adjustment problems in kindergarten: Can teachers make a difference? Social Development, 20, 33-50.

Campbell, S. B., \& Stauffenberg, C. V. (2007). Child characteristics and family processes that predict behavioral readiness. In A. Booth \& A. C. Crouter (Eds.), Disparities in school readiness: How families contribute to transitions to school (pp. 225-258). Mahwah, NJ: Erlbaum.

Crosnoe, R., \& Elder, G. H., Jr. (2004). Family dynamics, supportive relationships, and educational resilience during adolescence. Journal of Family Issues, 25, 571-602.

Cunningham, J. N., Kliewer, W., \& Garner, P. W. (2009). Emotion socialization, child emotion understanding and regulation, and adjustment in urban African American families: Differential associations across child gender. Development and Psychopathology, 21, 261-283.

Davis, H. A. (2003). Conceptualizing the role and influence of student-teacher relationships on children's social and cognitive development. Educational Psychologist, 38, 207-234.

Deci, E. L., \& Ryan, R. M. (2000). The "what" and "why" of goal pursuits: Human needs and the self-determination of behavior. Psychological Inquiry, 11, $227-268$.

Denham, S. A., \& Burton, R. (1996). A social-emotional intervention for at-risk 4-year olds. Journal of School Psychology, 34, 225-245.

Doumen, S., Koomen, H., Buyse, E., Wouters, S., \& Verschueren, K. (2012). Teacher and observer views on student-teacher relationships: Convergence across kindergarten and relations with student engagement. Journal of School Psychology, 50, 61-76.

Eisenberg, N., Losoya, S., Fabes, R., Guthrie, I., Reiser, M., Murphy, B., . . . Padgett, S. (2001). Parental socialization of children's dysregulated expression of emotion and externalizing problems. Journal of Family Psychology, $15,183-205$.

Entwisle, D. R., \& Alexander, K. L. (1998). Facilitating the transition to first grade: The nature of transition and research on factors affecting it. Elementary School Journal, 98, 351-364.

Galambos, N. L., Barker, E. T., \& Almeida, D. M. (2003). Parents do matter: Trajectories of change in externalizing and internalizing problems in early adolescence. Child Development, 74, 578-594.

Gauze, C., Bukowski, W. M., Aquan-Assee, J., \& Sippola, L. K. (1996). Interactions between family environment and friendship and associations with 
self-perceived well-being during early adolescence. Child Development, 67, 2201-2216.

Goodman, R. (1997). The Strengths and Difficulties Questionnaire: A research note. Journal of Child Psychology and Psychiatry, 38, 581-586.

Goodman, R., \& Scott, S. (1999). Comparing the Strengths and Difficulties Questionnaire and the Child Behavior Checklist: Is small beautiful? Journal of Abnormal Child Psychology, 27, 17-24.

Gray, M. R., \& Steinberg, L. (1999). Unpacking authoritative parenting: Reassessing a multidimensional construct. Journal of Marriage and Family, 61, 574-587.

Hamre, B. K., \& Pianta, R. C. (2001). Early teacher-child relationships and the trajectory of children's school outcomes through eighth grade. Child Development, 72, 625-638.

Hart, C. H., Newell, L. D., \& Olsen, S. F. (2003). Parenting skills and socialcommunicative competence in childhood. In J. O. Greene \& B. R. Burleson (Eds.), Handbook of communication and social interaction skills (pp. 753-797). Mahwah, NJ: Erlbaum.

Howes, C. (1999). Attachment relationships in the context of multiple caregivers. In J. Cassidy \& P. R. Shaver (Eds.), Handbook of attachment: Theory, research, and clinical applications (pp. 671-687). New York: Guildford Press.

Hughes, J., \& Chen, Q. (2011). Reciprocal effects of student-teacher and student-peer relatedness: Effects on academic self-efficacy. Journal of Applied Developmental Psychology, 32, 278-287.

Jennings, P. A., \& Greenberg, M. T. (2009). The prosocial classroom: Teacher social and emotional competence in relation to student and classroom outcomes. Review of Educational Research, 79, 491-525.

Johnson, S. R., Seidenfeld, A. M., Izard, C. E., \& Kobak, R. (2013). Can classroom emotional support enhance prosocial development among children with depressed caregivers? Early Childhood Research Quarterly, 28, 282-290.

Kiuru, N., Lerkkanen, M.-K., Niemi, P., Poskiparta, E., Ahonen, T., Poikkeus, A.-M., \& Nurmi, J.-E. (2013). The role of reading disability risk and environmental protective factors in children's reading fluency in grade 4. Reading Research Quarterly, 48, 349-368.

Kiuru, N., Pakarinen, E., Vasalampi, K., Silinskas, G., Aunola, K., Poikkeus, A.-M., . . . Nurmi, J.-E. (2014). Task-focused behavior mediates the associations between supportive interpersonal environments and students' academic performance. Psychological Science, 25, 1018-1024.

Koskelainen, M., Sourander, A., \& Kaljonen, A. (2000). The Strengths and Difficulties Questionnaire among Finnish school-aged children and adolescents. European Child \& Adolescent Psychiatry, 9, 277-284. 
Ladd, G. W. (1990). Having friends, keeping friends, making friends, and being liked by peers in the classroom: Predictors of children's early school adjustment. Child Development, 61, 1081-1100.

Ladd, G. W., Birch, S. H., \& Buhs, E. S. (1999). Children's social and scholastic lives in kindergarten: Related spheres of influence? Child Development, 58, $1168-1189$.

Ladd, G. W., \& Burgess, K. B. (2001). Do relational risks and protective factors moderate the linkages between childhood aggression and early psychological and school adjustment? Child Development, 72, 1579-1601.

La Paro, K. M., Pianta, R. C., \& Stuhlman, M. (2004). The Classroom Assessment Scoring System: Findings from the pre-kindergarten year. Elementary School Journal, 104, 409-426.

Laursen, B., \& Mooney, K. S. (2008). Relationship network quality: Adolescent adjustment and perceptions of relationships with parents and friends. American Journal of Orthopsychiatry, 78, 47-53.

Leflot, G., van Lier, P. A. C., Verschueren, K., Onghena, P., \& Colpin, H. (2011). Transactional associations among teacher support, peer social preference, and child externalizing behavior: A four-wave longitudinal study. Journal of Clinical Child and Adolescent Psychology, 40, 87-99.

Little, R. J. A. (1988). A test of missing completely at random for multivariate data with missing values. Journal of the American Statistical Association, 83, 1198-1202.

Little, M., \& Kobak, R. (2003). Emotional security with teachers and children's stress reactivity: A comparison of special-education and regular-education classrooms. Journal of Clinical Child and Adolescent Psychology, 32, $127-138$.

Mashburn, A. J., Pianta, R. C., Hamre, B. K., Downer, J. T., Barbarin, O. A., Bryant, D., . . Howes, C. (2008). Measures of classroom quality in prekindergarten and children's development of academic, language, and social skills. Child Development, 79, 732-749.

Meehan, B. T., Hughes, J. L., \& Cavell, T. A. (2003). Teacher-student relationships as compensatory resources for aggressive children. Child Development, 74, 1145-1157.

Muthén, L. K., \& Muthén, B. O. (1998-2013). Mplus Version 7 \& Mplus users' guide. Los Angeles: Muthén and Muthén.

Muthén, B. O., \& Satorra, A. (1995). Complex sample data in structural equation modeling. Sociological Methodology, 25, 267-316.

Niesel, R., \& Griebel, W. (2007). Enhancing the competence of transition systems through co-construction. In A.-W. Dunlop \& H. Fabian (Eds.), Informing transitions in the early years: Research, policy and practice (pp. 21-32). Maidenhead, England: McGraw-Hill/Open University Press. 
O'Connor, E., \& McCartney, K. (2007). Examining teacher-child relationships and achievement as part of an ecological model of development. American Educational Research Journal, 44, 340-369.

Ojanen, T., \& Perry, D. G. (2007). Relational schemas and the developing self: Perceptions of mother and of self as joint predictors of early adolescents' self-esteem. Developmental Psychology, 43, 1474-1483.

Pianta, R. C. (1999). Enhancing relationships between children and teachers. Washington, DC: American Psychological Association.

Pianta, R. C. (2001). The Student-Teacher Relationship Scale. Odessa, FL: Personality Assessment Research.

Pianta, R. C., \& Hamre, B. K. (2009). Conceptualization, measurement, and improvement of classroom processes: Standardized observation can leverage capacity. Educational Researcher, 38, 109-119.

Pianta, R. C., Nimetz, S. L., \& Bennett, E. (1997). Mother-child relationships, teacher-child relationships, and school outcomes in preschool and kindergarten. Early Childhood Research Quarterly, 12, 263-280.

Pianta, R. C., Steinberg, M. S., \& Rollins, K. B. (1995). The first two years of school: Teacher-child relationships and deflections in children's classroom adjustment. Development and Psychopathology, 7, 295-312.

Preacher, K. J., Curran, P. J., \& Bauer, D. J. (2006). Computational tools for probing interaction effects in multiple linear regression, multilevel modeling, and latent curve analysis. Journal of Educational and Behavioral Statistics, 31, 437-448.

Rimm-Kaufman, S. E., \& Pianta, R. C. (2000). An ecological perspective on the transition to kindergarten: A theoretical framework to guide empirical research. Journal of Applied Developmental Psychology, 21, 491-511.

Roberts, G. C., Block, J. H., \& Block, J. (1984). Continuity and change in parents' child-rearing practices. Child Development, 55, 586-597.

Roorda, D. L., Koomen, M. Y., Spilt, J. L., \& Oort, F. J. (2011). The influence of affective teacher-student relationships on students' school engagement and achievement: A meta-analytic approach. Review of Educational Research, 81, 493-529.

Rothbaum, F., Rosen, K. S., Pott, M., \& Beatty, M. (1995). Early parent-child relationships and later problem behavior: A longitudinal study. Merrill-Palmer Quarterly, 41, 133-151.

Sameroff, A. J. (1993). Models of development and developmental risk. In C. H. Zeanah Jr. (Ed.), Handbook of infant mental health (pp. 3-13). New York: Guilford Press.

Silver, R. B., Measelle, J. R., Armstrong, J. M., \& Essex, M. J. (2005). Trajectories of classroom externalizing behavior: Contributions of child characteristics, family characteristics, and the teacher-child relationship during the school transition. Journal of School Psychology, 43, 39-60. 
Siequeland, L., Kendall, P. C., \& Steinberg, L. (1996). Anxiety in children: Perceived family environments and observed family interaction. Journal of Clinical Child Psychology, 25, 225-237.

Skinner, E. A., \& Belmont, M. J. (1993). Motivation in the classroom: Reciprocal effects of teacher behavior and student engagement across the school year. Journal of Educational Psychology, 85, 571-581.

Spilt, J. L., \& Koomen, H. M. Y. (2009). Widening the view on teacher-child relationships: Teachers' narratives concerning disruptive versus nondisruptive children. School Psychology Review, 38, 86-101.

Spilt, J. L, Koomen, H. M., Thijs, J. T., \& van der Leij, A. (2012). Supporting teachers' relationships with disruptive children: The potential of relationshipfocused reflection. Attachment \& Human Development, 14, 305-318.

Statistics Finland. (2007). Statistical databases. Retrieved April 5, 2012, from www.stat.fi/tup/tilastotietokannat/index_en.html

Thijs, J. T., Koomen, H. M. Y., \& van der Leij, A. (2008). Teacher-child relationships and pedagogical practices: Considering the teacher's perspective. School Psychology Review, 37, 244-260.

Wang, M.-T., \& Eccles, J. S. (2012). Social support matters: Longitudinal effects of social support on three dimensions of school engagement from middle to high school. Child Development, 83, 877-895.

Wang, M.-T., Brinkworth, M., \& Eccles, J. (2013). Moderating effects of teacherstudent relationship in adolescent trajectories of emotional and behavioral adjustment. Developmental Psychology, 49, 690-705.

Wentzel, K. R. (1998). Social relationships and motivation in middle school: The role of parents, teachers, and peers. Journal of Educational Psychology, 90, 202-209.

Wentzel, K. R. (2002). Are effective teachers like good parents? Teaching styles and student adjustment in early adolescence. Child Development, 73, 287-301.

Wood, J. J., McLeod, B. D., Sigman, M., Hwang, W-C., \& Chu, B. C. (2003). Parenting and childhood anxiety: Theory, empirical findings, and future directions. Journal of Child Psychology \& Psychiatry \& Allied Disciplines, 44, 134-151. 